. . остюк, . . елен , . . усило

ст тье выполнен н лиз состояния и перспектив р звития учебно-трен жерных средств для подготовки специ листов втомобильной службы в ооруженных ил $x$ кр ины, обоснов ны р цион льные предложения относительно номенкл туры учебно-трен жерных средст в соответствии с реш емымиют з д ч ми.

лючевые слов: втомобильн я служб, учебно-трен жсерные средств, втомобильн я техник, втомобильный трен жерный комплекс, военн я втомобильн я техник, номенкл тур учебно-трен жеерных средств, ухопутные войск.

\title{
GROUND FOR RATIONAL NOMENCLATURE OF MODERN TRAINING FACILITIES FOR PREPARATION OF MOTOR-CAR SERVICE SPECIALISTS IN GROUND FORCES OF UKRAINIAN ARMED FORCES
}

V.V. Kostiuk, V.P. Belena, P.O. Rusilo

The analysis of state and development prospects of training facilities (TF) for preparation of motor-car service specialists in Armed Forces of Ukraine is done in the article, rational suggestions concerning the nomenclature of $(T F)$ in accordance with tasks, they fulfill, are grounded.

Keywords: motor-car service, training facilities (TF), motor vehicles, motor-car training complex, military motor vehicles, nomenclature of training facilities, Ground forces.

\subsection{2}

. . $\mathrm{p}$ сник, . . им $\mathrm{p}$, . . опович

$\kappa$ демія сухопутних військ імені гетьм н етр г йд чного, ввів

ирішення проблеми низької ефективності тренув льних з собів для підготовки особового скл ду військових ч стин і орг нів упр вління військ ми потребуе створення ефективних н вч льно-тренув льних з собів з м ксим льним використ нням комп'ютерних технологій. ст тті н основі н лізу суч сних досягнень в з стосув нні трен жерних з собів для підготовки особового скл ду бройних ил розвинутих держ в розгляд ється проблем створення суч сних ефективних н вч льно-тренув льних з собів для військ.

лючові слов : вч льно-тренув льні з соби, компютерні технологї̈, трен жмер, підготовк особового скл д, озброєння і військов технік .

\section{ступ}

ост новк проблеми. гідно з н лізом деяких пок зників якості основних типів існуючих в бройних ил х кр їни н вч льно-тренув льних 3 собів ( ) $[1]$ пок зник ступеня відповідності дій тих, хто н вч ється, ре льному процесу бойової роботи ст новить 0,59 , пок зник ступеня відповідності п р метрів т ктичної обст новки, що імітується, ре льним п р метр м - 0,3, пок зник контролю дій тих, хто н вч ється, $-0,18$, що явно недост тньо для ефективності н вч льного процесу. сновними причин ми т кої низької ефективності $\epsilon[1]$ :

- низький ступінь відповідності н вч льноінформ ційної моделі ре льним умов м бою; 
- незн чні можливості н явних

стосовно документув ння процесу бойової роботи розр хунків (обслуг);

- бр к у суч сних методик $\mathrm{x}$ системного підходу до втом тизов ної дид ктичної, психофізіологічної т медичної ді гностики діяльності тих, хто н вч ється;

- відсутність можливості керув ння іміт цією дій умовного противник в процесі тренув ння;

- нез безпеченість суч сними

зл годженості дій підрозділів і ч стин н фоні єдиної опер тивно-т ктичної обст новки.

н ліз ост нніх досліджень і публік цій. сновні концепції, н прями і проблеми розвитку

в бройних ил $\mathrm{x}$ кр їни зн йшли своє висвітлення в ф хових вид ннях іністерств оборони (,, ук і оборон ", ,, родн рмія", , ійсько кр їни”, труди к демії бройних ил кр їни ( ціон льної к демії оборони кр їни) і ін.), н уково-дослідних робот $x$

укового центр (м. ьвів) $[1,2]$, укового центру ртилерії (м. уми) [3] тощо. кр їнські дослідники ( уозвитку к . ., к дей . ., евченко . ., ригунов . . інченко . ., оп . ., ртемов .. $\mathrm{i}$ ін.), почин ючи 3 кінця дев'яностих років минулого століття, створили необхідну теоретичну б зу основ розвитку перспективних в бройних ил $\mathrm{x}$ кр їни.

етою ст тті $€$ обгрунтув ння необхідності м ксим льного використ ння комп'ютерних технологій при створенні для підготовки особового скл ду військових ч стин.

\section{сновний м тері л}

ри орг ніз ції бойової i опер тивної підготовки все більше ув ги приділяється 3 стосув нню трен жних 3 собів. ьому сприяють н ступні об'єктивні чинники [1]:

-зрост ння в ртості проведення тр диційних 3 ходів підготовки військ. кий шлях потребує величезних витр т м тері льних ресурсів (у тому числі п льного) і пов'яз ний зі швидким витр ч нням ресурсу озброєння т військової техніки ( );

- 3 ост нні роки різко зменшил ся в ртість обчислюв льної техніки і прогр мних з собів, що є м тері льною основою створення високоефективних трен жерів і трен жерних систем;

- корінним чином змінил ся роль людського чинник у війні. нік льність кожної бойової ситу ції, необхідність вибору для неї способу ведення бойових дій пост вил людину в озброєній боротьбі н передній пл н, що не могло не позн читися н посиленні ув ги до розвитку трен жних $з$ собів бойової і опер тивної підготовки перш 3 все н основі з стосув ння комп'ютерних технологій;

- 3 няття 3 л лученням бойової техніки з вд ють серйозної шкоди н вколишньому середовищу т потребують витр тних з ходів екологічної безпеки (н віть 3 умови використ ння спеці льних військових полігонів і н вч льних центрів).

н ліз системи військового Н вЧ ння особового скл ду сухопутних військ рмій розвинутих у військовому відношенні держ в [1 - 8] пок з в, що:

- при зберіг нні високої інтенсивності проведення 3 ходів 3 бойової т опер тивної підготовки продовжується стійк тенденція до под льшого скорочення 3 ходів 3 ре льним 3 лученням особового скл ду i використ нням бойової техніки, впров дження в н вч ння шт бів і військ нових форм і методів 3 використ нням трен жерів т іміт торів, в першу чергу електронних. К, н прикл д, в сухопутних військ х імеччини є більше 2000 суч сних електронних трен жерів, які призн чені для проведення з нять i тренув нь 3 вогневої і т ктико-спеці льної підготовки, дуельних тренув нь, іміт ції вогневих 3 собів тощо. ля підготовки мех ніків-водіїв успішно 3 стосовуються трен жери, обл дн ні суч сною системою візу ліз ції, як дозволяє відобр зити н вч льно-бойову обст новку у ре льному м сшт бі ч су. икорист ння в н вч нні електронних трен жерів і комп'ютерів н д $€$ унік льну можливість проведення двосторонніх н вч нь 3 можливістю вибору будь-якого противник ;

- особливе місце в г лузі розробки трен жерів в кр їн $\mathrm{x} \quad 3$ йм $€$ створення іміт ційномоделюючих комплексів, які осн щені електронними з соб ми обробки інформ ції т призн чені для н вч ння ком ндирів і шт бів у ході ком ндно-шт бних н вч нь. кі системи імітують бойову обст новку, з безпечують відобр ження результ тів н вч льно-бойових дій н електронних топогр фічних к рт х i використовуються, як пр вило, н фоні зг льновійськових т ктичних Н вч нь. рикл дом $є$ розроблений $\mathrm{y}$ мобільний втом тизов ний н вч льний ком Ндний пункт JESS (Joint Exercise Support System), призн чений для н вч ння i тренув ння шт бів бриг д, дивізій і корпусів. перше систем бул використ н у ході рмійських у листоп ді 1985 року. о скл ду обл дн ння системи JESS входять 14 (одн - для моделюв ння і іміт ції бойової обст новки, 13 - для з безпечення роботи 
контрольних ст нцій опер торів) і периферійне обл дн ння;

- 3 стосув ння т нкових трен жерів н основі широкого з стосув ння комп'ютерних технологій привело до економії пробігу т нків н 60\%, витр ти боєприп сів н 25\%, н вч льного ч су н $30 \%$.

ртість проведення 4-годинного польового з няття 3 т нковим взводом скл д є 5-10 тис. дол рів 3 умов, що н вч льн стрільб ведеться 3 використ нням вкЛ дного ствол (в ртість одного пострілу 3,5 дол $\mathrm{p}, \quad$ шт тного боєприп с (пострілу), н прикл д, для 5 тис. дол рів). розр хунк ми військових спеці лістів , 3 стосув ння в бойовій підготовці іміт тор MODEL-70 WEAPONEER дозволяє економити тільки н боєприп с х 228 тис. дол рів н рік. ожен військовослужбовець, який виконує впр ву зі стрільби н іміт торі, економить 348 п тронів. икорист ння у т нковому б т льйоні трен жер для стрільби із т нкової пушки, в з лежності від к лібру, д є економію $0,3-2$ млн. дол рів н рік. о цієї суми слід дод ти ще 0,3 млн. дол рів, які скл д ють економію н витр т $\mathrm{x}$ п льного $\mathrm{i}$ моторесурсів (1 н вч льний ч с підготовки екіп жу т нк “ еоп рд-2” ( імеччин ) коштує м йже 15 тис. євро). ри цьому в ртість трен жер окупиться з 1-3 роки, 3 тр ти н трен жери д ного типу від з г льної в ртості з купівлі т нків не перевищують 1,5 - 2\%;

- особливе місце в системі бойової підготовки 3 йм ють н вч льні центри. прикл д, в рмії створен ціл мереж т ких н вч льних центрів, технічн осн щеність яких дозволяє з 2 2-4 тижні здійснити відпр цюв ння з вд нь одиночної підготовки, зл годження підрозділів і орг нів упр вління. ля з безпечення єдиного керівництв всім комплексом робіт 3 розвитку б зи вдоскон лення бойової підготовки і будівництву сухопутних військ ще в 1970-х рок х було створено нове ком ндув ння „TREDOC”.

ро роль і зн чущість робіт в г лузі розвитку з собів і технологій н вч ння в рміях іноземних держ в кр сномовно свідчить і рівень фін нсув ння, що виділяється н . $\quad$ к, н н уково-дослідні і випробув льно-конструкторські роботи виділяється $3-5 \%$, н серійні з купівлі-близько $10 \%$ від 3 г льного фін нсув ння, що виділяється н з безпечення військ

рен жерн і н вч льн комп'ютерн 63 для підготовки військових ф хівців, що створен в рміях $\mathrm{i}$ інших кр їн , дозволяе відпр цьовув ти до $90 \%$ впр в, норм тивів і з вд нь н трен жер х.

елике зн чення 3 безпеченню військ суч сними трен жерними з соб ми приділяється в сухопутних військ х осійської едер ції, де пр ктично н кожен зр зок розроблений свій трен жер.

скільки ефективні суч сні із

3 стосув нням комп'ютерних технологій в сухопутних військ х осійської едер ції, вк зують н ступні ф кти [2]:

- в мотострілецьких і т нкових ч стин х 3 стосув ння трен жерів скорочує розхід моторесурсу н $30 \%$;

- в ві ції в ртість однієї години з нять н трен жері в 7-9 р зів дешевше в ртості польоту н с мольоті. икорист ння трен жерів при відпр цюв нні у пілотів н вичок польоту н 40-50\% скорочує трив лість ре кції пілот н прості дії т н $35-40 \%-$ н скл дні;

- в ртилерії використ ння комплексного трен жер н основі 14,5-міліметрового н кл дного ствол д $€$ можливість проводити н вч ння г рм тних обслуг і підтримув ти їх н вченість без використ ння шт тної бойової техніки. ей трен жер скорочує трив лість н вч ння в 10$15 \mathrm{p}$ зів, в ртість н вч ння однієї обслуги - в 13-16 $\mathrm{p}$ зів.

військ осійської едер ції поч ли поступ ти комп'ютерні кл си і типові комплекти комп'ютерних інформ ційних 3 собів 3 н бором н вч льних електронних прогр м. х 3 стосув ння дозволяе скоротити ч с н вч ння, з безпечуючи зрост ння професійного рівня військовослужбовців.

ур хув нням пл нов ного скорочення термінів служби з призовом, з вершення переходу ряду ч стин н контр ктний спосіб комплектув ння кту льним ст ло з вд ння розгорт ння н вч льної комп'ютерно-інформ ційної б зи.

озробк , виготовлення і впров дження в військ розвинутих держ в комп'ютерних трен жерних з собів н пр влені н вирішення н ступних основних з вд нь [2]:

- усунути (звести до мінімуму) нег тивний вплив бойової підготовки військ н н вколишнє середовище;

- підвищити бойову готовність екіп жів (бойових розр хунків) з р хунок збільшення ч су тренув нь, різном нітності бойових ситу цій, що моделюються як н ре льній, побудов ній н основі цифрових к рт, т к і н виг д ній місцевості, широти охв ту з лучених до тренув ння військовослужбовців від рядового до вищого ком ндного скл ду, т кож відпр цюв ння вз ємодії всередині екіп жу (бойового розр хунку), підрозділу, між підрозділ ми, ч стин ми і род ми військ;

- проводити підготовку екіп жів (бойових розр хунків) в умов х, які неможливо змоделюв ти 
3 використ нням ре льної техніки, н прикл д, в умов х з стосув ння зброї м сового ур ження, використ ння в місті, серед мирного н селення;

- ЗН чно знизити собів ртість н вч нНя 3 p хунок економії п льного і моторесурсу бойової і спеці льної техніки.

\section{иходячи із вищеск 3 ного і вр ховуючи результ ти досліджень $[2,4,5]$, можн конст тув ти н ступне:}

1. озвиток і зменшення в ртості комп'ютерної техніки д є можливість зн чно зменшити в ртість , які створені н основі 3 стосув ння комп'ютерних технологій i 3 безпечують необхідний рівень н вченості особового скл ду, в порівнянні 3 , створеними без 3 стосув ння комп'ютерних технологій $(1<3$ при =0,9). лежність рівня підготовки особового скл ду 3 3 стосув нням від їх в ртості пок $3 \mathrm{H}$ н рис. 1.

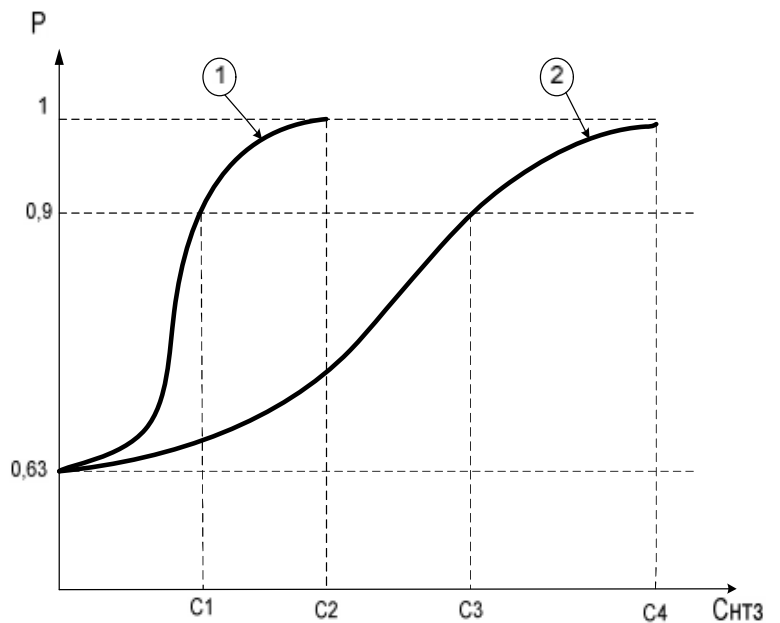

uc. 1. лежність рівня підготовки особового скл ду н ( ) від в ртості ( нтз):

1, 3-в ртість , що з безпечує мінім льний критерій гр ничної досяжності підготовки військових $ф$ хівців ( $=0,9)$

2, 4-в ртість , що з безпечує м ксим льний критерій гр ничної досяжності підготовки військових ф хівців ( = 1)

1 - зежність ( нтз) для 3 з стосув нням комп'ютерних технологій

$2-3$ лежність ( нтз) для без з стосув ння комп'ютерних технологій

2. 3 зрост нням в ртості

збільшується ефективність 3 стосув ння в н вч льному процесі

(щодо зменшення його відносної в ртості нтз/ овт), особливо створених 3 використ нням комп’ютерних технологій. им більш в ртість зр зк , тим менші відносні витр ти н підготовку військових ф хівців ( нтз/ овт) 3

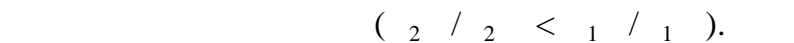
збільшенням в ртості зр зк ефективність 3 з стосув нням комп'ютерних технологій зрост є $\left(\Delta_{2 \text { нтз }}>\Delta\right.$ 1нтз $_{\text {. }}$. лежність в ртості (кошти Н створення, з купівлю, обслуговув ння і м тері льно технічне 3 безпечення) , що 3 безпечують підготовку військових фхівців не нижче гр ничного рівня, від в ртості (Кошти н створення, 3 купівлю, обслуговув ння і м тері льно технічне з безпечення) пок 3 н н рис. 2.

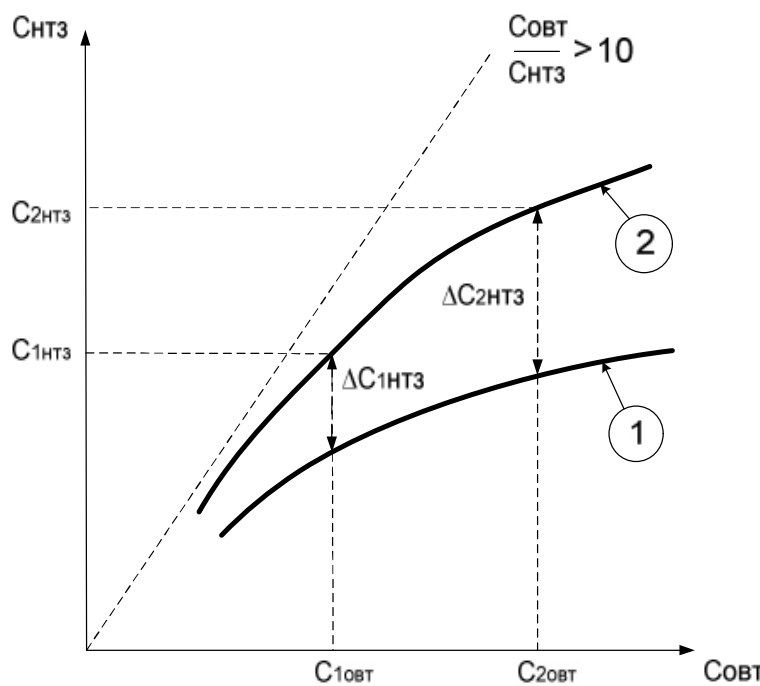

uc. 2. лежність в ртості ( нтз), що з безпечують підготовку військових ф хівців не нижче гр ничного рівня, від в ртості ( овт):

1 - 3 лежність нт3 ( овт) для 33 стосув нням комп'ютерних технологій

2-з лежність нтз ( овт) для без з стосув ння комп'ютерних технологій

\section{ИСН ОВ КИ}

Ким чином, зрост ння скл дності і в ртості , розвиток форм і способів з стосув ння військ призводить до збільшення витр т Н Н ВЧ ння особового скл ду (коштів н створення, з купівлю, обслуговув ння, м тері льно-технічне з безпечення i т.П.).

метою 3 безпечення необхідного рівня підготовки особового скл ду військ, зменшення витр т Н його Н вч ння в основу розвитку для підготовки особового скл ду військових ч стин і орг нів упр вління військ ми необхідно покл сти з стосув ння комп’ютерних технологій. 


\section{писок літер тури}

1. н ліз суч сного $\mathrm{cm}$ ну $m$ обгрунтув ння н прямків розвитку н вч льно-тренув льних з собів p кетних військ $i$ ртилерії: віт про (з ключний). уковий центрр ухопутних військ. - інв. № 287 від 15.10.2009 року. - ввів, 2008. - 55 c.

2. озробк пропозицій щодо створення перспективних н вч льно-тренув льних з собів р кетних військ $i$ ртилерії: віт про (з ключний). уковий центр уххопутних військ. - інв. № 314 від 25.11.2009 року. - ввів, 2009. -83 c.

3. пис обрису, структури $m$ вимог 3 призн ченням до уніфіков ного трен жерномоделюв льного комплексу $m$ його скл дових: віт про (проміжний). уковий центр ртилерії. інв. № 3565. - уми, 2002. $-181 \mathrm{c}$.

4. роб н. . етодик оцінки ефективності н ви льно-трен жерних комплексів підготовки ф хівців ухопутних військ. исерт иія $\kappa$ ндид $m$ військових н $у к .-., 2005 .-.58-127$.
5. усн к. . нформ ційні технологї̈ для військ. укові $m$ орг ніз иійні спекти розроблення $m$ впров дження суч сних трен жерно-моделюючих з собів y бройних ил $х$ кр їни // родн рмія. - 2001. 24 листоп $\partial$.

6. усн к. ., ижняк . . вірту льної ре льності y світ професіон лізму. о перспектив розвитку трен жерно-моделюючих з собів у системі бойової опер тивної підготовки військ (сил) // ійсько кр їни. 2002.- №3-4 - . 16-18.

7. рфеев., спользов ние компьютерной техники для обучения войск ( рубежсный опыт) / . . рфеев, . . добин, . . етровський // оенн я мысль. 1997. - № 1. - . 74-78.

8 йфетдинов. . еформиров ние боевой подготовки: компьютерные формы обучения / . . йфетдинов // оенн я мысль. 1998. - №36. - . 12$16,77-81$.

дійщл до редк кції 11.09.2010 p.

ецензент: к ндид т військових н ук . . роб н, к демія сухопутних військ, ьвів.

. . p сник, . . ым p, . . опович

ешение проблемы низкой эффективности тренировочных средств для подготовки личного сост в воинских ч стей орг нов упр вления войск ми требует созд ния эффективных учебно-тренировочных средств с м ксим льным использов нием компьютерных технологий. ст тье н основе н лиз современных достижений в применении трен жерных средств для подготовки личного сост в вооруженных сил р звитых госуд рств р ссм трив ется проблем созд ния современных эффективных учебно-тренировочных средств для войск.

лючевые слов : учебно-тренировочные средств, компьютерные технологии, трен жер, подготовк личного сост в, вооружение и военн я техник.

\title{
SUBSTANTIATION OF EFFECTIVENESS OF EDUCATIONAL AND TRAINING FACILITIES CREATION FOR THE ARMED FORCES TRAINING ON THE BASIS OF MAXIMUM USAGE OF COMPUTER TECHNOLOGIES
}

\author{
Y.V. Krasnyk, O.V.Rymar, T. D. Popovych
}

Solution to the problem of low efficiency of training facilities for the training of personnel of command and control elements and units requires the creation of the effective educational and training facilities with maximum usage of computer technologies. The problem of creation of modern effective educational and training facilities for the armed forces is examined in this article on the analysis of contemporary achievements in training facilities application for the training of the armed forces of the developed countries.

Keywords: educational and training facilities, computer technologies, trainer, training of personnel, armament and military materiel 